Portland State University

PDXScholar

Chemistry Faculty Publications and

Presentations

Chemistry

$5-2001$

\title{
Trimethylsulfonium Methanesulfonate
}

Frank R. Fronczek

Louisiana State University

Rolanda J. Johnson

Robert M. Strongin

Portland State University, strongin@pdx.edu

Follow this and additional works at: https://pdxscholar.library.pdx.edu/chem_fac

Part of the Organic Chemistry Commons

Let us know how access to this document benefits you.

\section{Citation Details}

Fronczek, F., Johnson, R., \& Strongin, R. (2001). Trimethylsulfonium methanesulfonate. Acta Crystallographica. Section E, Structure Reports, 57 (Pt 5), 447-448.

This Article is brought to you for free and open access. It has been accepted for inclusion in Chemistry Faculty Publications and Presentations by an authorized administrator of PDXScholar. Please contact us if we can make this document more accessible: pdxscholar@pdx.edu. 


\title{
Structure Reports
}

Online

ISSN 1600-5368

\section{Trimethylsulfonium methanesulfonate}

\author{
Frank R. Fronczek, Rolanda J. Johnson and Robert M. Strongin
}

Acta Cryst. (2001). E57, 0447-0448

Copyright (C) International Union of Crystallography

Author(s) of this paper may load this reprint on their own web site or institutional repository provided that this cover page is retained. Republication of this article or its storage in electronic databases other than as specified above is not permitted without prior permission in writing from the IUCr.

For further information see http://journals.iucr.org/services/authorrights.html

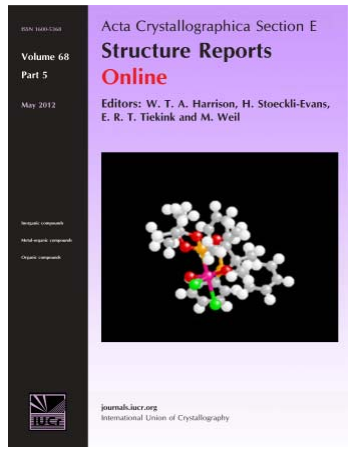

Acta Crystallographica Section E: Structure Reports Online is the IUCr's highly popular open-access structural journal. It provides a simple and easily accessible publication mechanism for the growing number of inorganic, metal-organic and organic crystal structure determinations. The electronic submission, validation, refereeing and publication facilities of the journal ensure very rapid and high-quality publication, whilst key indicators and validation reports provide measures of structural reliability. The average publication time is less than one month. Articles are published in a short-format style with enhanced supplementary materials. Each publication consists of a complete package - the published article, HTML and PDF supplements, CIF, structure factors, graphics, and any other submitted supplementary files.

Crystallography Journals Online is available from journals.iucr.org 
Acta Crystallographica Section E

Structure Reports

Online

ISSN 1600-5368

Frank R. Fronczek,* Rolanda J. Johnson and Robert M. Strongin

Department of Chemistry, Louisiana State

University, Baton Rouge, LA 70803-1804, USA

Correspondence e-mail:

fronz@chxray1.chem.Isu.edu

\section{Key indicators}

Single-crystal X-ray study

$T=120 \mathrm{~K}$

Mean $\sigma(\mathrm{S}-\mathrm{O})=0.002 \AA$

$R$ factor $=0.039$

$w R$ factor $=0.089$

Data-to-parameter ratio $=17.7$

For details of how these key indicators were automatically derived from the article, see http://journals.iucr.org/e.

\section{Trimethylsulfonium methanesulfonate}

In the title compound, $\mathrm{C}_{3} \mathrm{H}_{9} \mathrm{~S}^{+} . \mathrm{CH}_{3} \mathrm{O}_{3} \mathrm{~S}^{-}$, a thermal decomposition product of dimethyl sulfoxide, both cation and anion lie on mirror planes. In the cation, the S atom lies 0.792 (2) $\AA$ out of the plane defined by the three $\mathrm{C}$ atoms, with $\mathrm{S}-\mathrm{C}$ distances of 1.781 (2) and 1.786 (3) $\AA$. In the anion, the $\mathrm{S}-\mathrm{O}$ distances are $1.4556(14)$ and 1.4646 (19) $\AA$, and the S-C distance is 1.759 (3) $\AA$.

\section{Comment}

We have been studying the structure and mechanism of formation of colored products derived from resorcinarene macrocycles upon heating in dimethyl sulfoxide (DMSO) (Lewis et al., 1997, 2000; Davis et al., 1999). We isolated the title compound, (I), a decomposition product formed by prolonged heating of a solution of macrocycle in DMSO, and determined its structure to ascertain its identity. While 38 salts of the trimethylsulfonium ion and 62 salts of the methylsulfonate anion are present in the Cambridge Structural Database (December 2000, 224400 entries; Allen \& Kennard, 1993), the structure of the title compound has not been previously reported. Decomposition of DMSO or its complexes to form trimethylsulfonium methanesulfonate has been previously reported as a result of heating (Banci, 1967; Arsenin et al., 1988) and $\gamma$ irradiation (Gutierrez et al., 1977).<smiles>C[C+]CCC</smiles><smiles>[CH]CC[AsH3]</smiles>

(I)

Both cation and anion lie across crystallographic mirrors. In the cation, the $S$ atom lies 0.792 (2) $\AA$ out of the plane defined by the three $\mathrm{C}$ atoms. Geometric parameters (Table 1) are normal. Most of the $\mathrm{H}$ atoms are involved in $\mathrm{C}-\mathrm{H} \cdots \mathrm{O}$ hydrogen bonding (Table 2)

\section{Experimental}

For the preparation of (I), the tetramethylresorc[4]arene 2,8,14,20tetramethylpentacyclo[19.3.1.13,7.19,13.115,19] octacosa-1(25),3,5,7(28),9,11,13(27),15,17,19(26),21,23-dodecaene-4,6,10,12,16,18,22,24octol $(250 \mathrm{mg}, 0.46 \mathrm{mmol})$ was placed in a sealed tube along with $12 \mathrm{ml}$ of DMSO and $3 \mathrm{ml}$ of water. The mixture was heated at $493 \mathrm{~K}$ for $36 \mathrm{~h}$. An aliquot was removed, and the solvent evaporated, yielding colorless crystals of the title compound.
Received 5 April 2001 Accepted 20 April 2001 Online 26 April 2001
C 2001 International Union of Crystallography

Printed in Great Britain - all rights reserved 
Crystal data

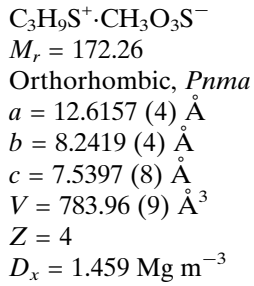

Mo $K \alpha$ radiation

Cell parameters from 7642

reflections

$\theta=2.5-30.0^{\circ}$

$\mu=0.62 \mathrm{~mm}^{-1}$

$T=120 \mathrm{~K}$

Plate, colorless

$0.12 \times 0.10 \times 0.02 \mathrm{~mm}$

\section{Data collection}

KappaCCD diffractometer (with Oxford Cryosystems Cryostream cooler)

$\omega$ scans with $\kappa$ offsets

Absorption correction: multi-scan (HKL SCALEPACK; Otwinowski \& Minor, 1997)

$T_{\min }=0.936, T_{\max }=0.988$

\section{Refinement}

Refinement on $F^{2}$

$R\left[F^{2}>2 \sigma\left(F^{2}\right)\right]=0.039$

$w R\left(F^{2}\right)=0.089$

$S=1.02$

1222 reflections

69 parameters

Only coordinates of $\mathrm{H}$ atoms

refined

Table 1

Selected geometric parameters $\left(\AA,^{\circ}\right)$.

\begin{tabular}{llll}
\hline $\mathrm{S} 1-\mathrm{O} 1$ & $1.4646(19)$ & $\mathrm{S} 2-\mathrm{C} 2$ & $1.786(3)$ \\
$\mathrm{S} 1-\mathrm{O} 2$ & $1.4556(14)$ & $\mathrm{S} 2-\mathrm{C} 3$ & $1.781(2)$ \\
$\mathrm{S} 1-\mathrm{C} 1$ & $1.759(3)$ & & \\
$\mathrm{O} 2-\mathrm{S} 1-\mathrm{O} 1$ & $112.20(7)$ & $\mathrm{O} 2-\mathrm{S} 1-\mathrm{C} 1$ & $106.11(8)$ \\
$\mathrm{O} 2{ }^{\mathrm{i}}-\mathrm{S} 1-\mathrm{O} 2$ & $113.45(12)$ & $\mathrm{C} 3-\mathrm{S} 2-\mathrm{C} 3^{\mathrm{ii}}$ & $101.31(15)$ \\
$\mathrm{O} 1-\mathrm{S} 1-\mathrm{C} 1$ & $106.11(13)$ & $\mathrm{C} 3-\mathrm{S} 2-\mathrm{C} 2$ & $102.00(10)$ \\
\hline
\end{tabular}

Symmetry codes: (i) $x, \frac{1}{2}-y, z$; (ii) $x, \frac{3}{2}-y, z$.

$w=1 /\left[\sigma^{2}\left(F_{o}^{2}\right)+(0.0326 P)^{2}\right.$ $+0.2622 P]$

where $P=\left(F_{o}{ }^{2}+2 F_{c}^{2}\right) / 3$

$(\Delta / \sigma)_{\max }<0.001$

$\Delta \rho_{\max }=0.40 \mathrm{e}^{-3}$

$\Delta \rho_{\min }=-0.37 \mathrm{e} \AA^{-3}$

Extinction correction: SHELXL97

Extinction coefficient: 0.0067 (18)

Table 2

Hydrogen-bonding geometry $\left(\AA{ }^{\circ},{ }^{\circ}\right)$.

\begin{tabular}{lllll}
\hline$D-\mathrm{H} \cdots A$ & $D-\mathrm{H}$ & $\mathrm{H} \cdots A$ & $D \cdots A$ & $D-\mathrm{H} \cdots A$ \\
\hline $\mathrm{C} 1-\mathrm{H} 1 B \cdots \mathrm{O} 2^{\mathrm{i}}$ & $0.95(2)$ & $2.54(2)$ & $3.463(2)$ & $163.5(18)$ \\
$\mathrm{C} 2-\mathrm{H} 2 A \cdots \mathrm{O} 1^{\mathrm{ii}}$ & $1.06(3)$ & $2.41(3)$ & $3.382(4)$ & $152(2)$ \\
$\mathrm{C} 3-\mathrm{H} 3 A \cdots \mathrm{O} 1^{\mathrm{ii}}$ & $0.97(2)$ & $2.48(2)$ & $3.388(3)$ & $156.0(19)$ \\
$\mathrm{C} 3-\mathrm{H} 3 B \cdots \mathrm{O} 2^{\mathrm{iii}}$ & $0.95(2)$ & $2.44(2)$ & $3.279(3)$ & $147.3(19)$ \\
$\mathrm{C} 3-\mathrm{H} 3 C \cdots \mathrm{O} 1$ & $0.92(3)$ & $2.41(3)$ & $3.280(2)$ & $157.1(19)$ \\
\hline
\end{tabular}

Symmetry codes: (i) $\frac{3}{2}-x,-y, z-\frac{1}{2}$; (ii) $1-x, \frac{1}{2}+y,-z$; (iii) $1-x, \frac{1}{2}+y, 1-z$.

The coordinates of $\mathrm{H}$ atoms were refined, while their isotropic displacement parameters were assigned as $U_{\text {iso }}=1.5 U_{\text {eq }}$ of the attached atom.
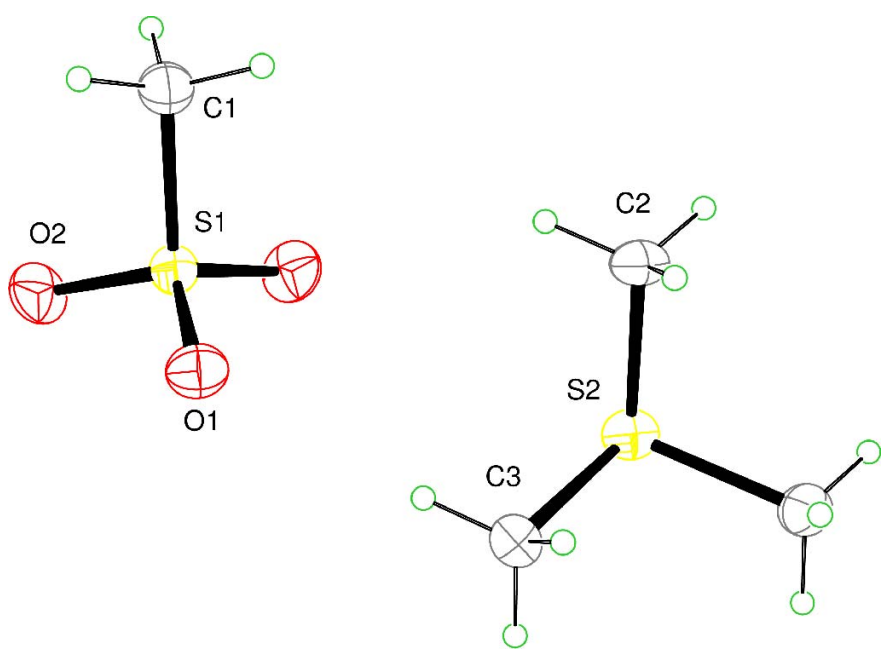

Figure 1

The atom-numbering scheme for (I) with ellipsoids at the $50 \%$ probability level.

Data collection: COLLECT (Nonius, 2000); cell refinement: $D E N Z O$ and SCALEPACK; data reduction: DENZO and SCALEPACK (Otwinowski \& Minor, 1997); program(s) used to solve structure: SIR (Altomare et al., 1994); program(s) used to refine structure: SHELXL97 (Sheldrick, 1997); molecular graphics: ORTEP-3 (Farrugia, 1997); software used to prepare material for publication: SHELXL97.

The purchase of the diffractometer was made possible by grant No. LEQSF(1999-2000)-ESH-TR-13, administered by the Louisiana Board of Regents.

\section{References}

Allen, F. H. \& Kennard, O. (1993). Chem. Des. Autom. News, 8, 1, 31-37. Altomare, A., Cascarano, G., Giacovazzo, C. \& Guagliardi, A. (1994). J. Appl. Cryst. 27, 435.

Arsenin, K. I., Malinko, L. A., Sheka, I. A., Pishchai, I. Y., Tikhonova, R. V., Kolotio, L. V. \& Antishko, A. N. (1988). Zh. Obshch. Khim. 58, 2102-2109. Banci, F. (1967). Ann. Chim. 57, 549-554.

Davis, C. J., Lewis, P. T., McCarroll, M. E., Reed, M. W., Cueto, R. \& Strongin, R. M. (1999). Org. Lett. 1, 331-334.

Farrugia, L. J. (1997). J. Appl. Cryst. 30, 565.

Gutierrez, M. C., Barrra, R., Sanz, H. \& Parellada, R. (1977). An. Quim. 73, 520-526.

Lewis, P. T., Davis, C. J., Cabell, L. A., He, M., Read, M. W., McCarroll, M. E. \& Strongin, R. M. (2000). Org. Lett. 2, 589-592.

Lewis, P. T., Davis, C. J., Saraiva, M. C., Treleavan, D., McCarley, T. \& Strongin, R. M. (1997). J. Org. Chem. 62, 6110-6111.

Nonius (2000). COLLECT. Nonius BV, Delft, The Netherlands.

Otwinowski, Z. \& Minor, W. (1997). Methods Enzymol. 276, 307-326.

Sheldrick, G. (1997). SHELXL97. University of Göttingen, Germany. 